\title{
EFL BRAZILIAN TEACHERS IN THE HYPERMODERN WORLD: PRÊT-À-PORTER SUBJECTS, SOCIAL MEDIA AND DISCOURSE
}

\section{PROFESSORES BRASILEIROS DE ILE NO MUNDO HIPERMODERNO: SUJEITOS PRÊT-À-PORTER, MÍDIA SOCIAL E DISCURSO}

\section{Maria de Fátima Silva Amarante* Eliane Righi de Andrade Eliane Fernandes Azzari}

\begin{abstract}
As researchers, we have been increasingly drawn to focus our investigation on both teachers' and students' posts on social media online networks, especially those held in community pages. Our aim is to reflect upon the representations and identity processes which have emerged from objectifying and/or subjectifying processes which are constituted by / constituting of power/knowledge relationships, established by the means of digitalmediatic discourse. We believe that the study of the interconnectivity between identity and technology in the identity constituting process of educational subjects will somehow contribute to clarify the implications that identity practices hold in the schooling of educational managers/stakeholders and teachers as well as to in-service teachers' instruction. Adopting a discursive-deconstructive perspective of Discourse Analysis, we look upon some posts taken from interactions on social network pages on Facebook. The underlying theoretical and methodological views are grounded on Foucault's literature discussions of power and subjectivity and on the discussions proposed by Ferreira (2008). The latter offers us a methodological-analytic perspective for the network discourse based on the rhizome structure developed by Deleuze \& Guatarri (2000). We then borrow from Lipovetzky \& Seroy's (2005.2008.2015)discussions our take on contemporary processes and society. Grounded in Foucault's perspective of language as a social practice; an action upon / onto others (FOUCAULT, 1996) we see that Facebook communities might be unveiled as disciplinary utilities which are a perfect match to the consumerist contemporary society - one where anthropophagical and autophagic processes rein. The analysis highlights the constitution of a hedonistic subject which shows up from both anthropophagical and autophagic processes materialized by instances of auto-referential/ referential mentions translated into digital (multimodal) illustrations and by exaggeratedly recalling to self-
\end{abstract}

\footnotetext{
* Pontificia Universidade Católica de Campinas, Campinas (SP), Brasil. fatimaamarante@uol.com.br; Pontificia Universidade Católica de Campinas, Campinas (SP), Brasil. elianerighi@terra.com.br, Universidade Estadual de Campinas, Campinas (SP), Brasil. elianeazzari@terra.com.br
} 
narratives. Such narratives suggest an attempt to answer a hypertrophied aesthetical call from a hyper Narcissus which has strategically been construed as an irresistible Don Juan. Key-words: technology; subjectivity; EFL teachers.

\section{RESUMO}

Postagens publicadas por professores e alunos em redes sociais, em especial em páginas de comunidades, têm sido objeto de nossa atenção, com o objetivo de refletir sobre representações e sobre os processos identitários que emergem dos processos de objetificação e de subjetivação constituídos por e constituintes de relações de poder/ saber que se estabelecem no/pelo discurso midiático-digital. Pensar o imbricamento entre identidade e tecnologia na constituição identitária dos sujeitos educacionais, de nosso ponto de vista, pode contribuir para o entendimento das implicações das práticas identitárias para a formação de gestores educacionais e professores e para a capacitação de professores em serviço. Assim, tomando uma perspectiva discursivo-desconstrutivista para a Análise do Discurso, examinamos postagens publicadas na rede social Facebook. A fundamentação teórico-metodológica se pauta em estudos foucaultianos acerca de poder e subjetividade e na proposta de Ferreira (2008), no sentido de considerar a estrutura rizomática de Deleuze \& Guatarri (2000) como um método para analisar o discurso das redes. Emprestamos, ainda, de Lipovetzky \& Seroy $(2005,2008,2015)$, considerações sobre os processos que constituem a contemporaneidade. Portanto, inseridos na perspectiva foucaultiana de que a linguagem é prática social, é ação sobre outros (Foucault, 1980), partimos da expectativa de que as comunidades facebookianas podem se revelar como dispositivos disciplinares bem ao gosto da sociedade de consumo contemporânea em que imperam processos antropofágicos e autofágicos. O que se sobressai da análise é a constituição de um sujeito hedonista que se nos apresenta em processos antropofágicos e autofágicos que se materializam, por exemplo, na recorrência à auto-referenciação e referenciação em ilustrações imagéticas e digitais e no exacerbado recurso à narrativa de si com efeito de sentido de atendimento a uma demanda hipertrofiada estetizante de um hiper Narciso que, estrategicamente, constrói-se como um irresistível Don Juan.

Palavras-chave: tecnologia; subjetividade; professores de ILE.

\section{INTRODUCTION}

We are currently living in a world reshaped and permeated by the new (digital) technologies - present in every inch of our daily procedures and routines - a contemporary process in which we have been deeply inserted, as stated by Lipovetsky and Seroy (2008). As a result, social media participation and interactions have become a trend, making it easier and faster to circulate discourses and thus offering us, researchers, opportunities abundant enough to investigate the processes through which identities and subjectivities are being constituted in/through such discourses.

In this article, we are particularly interested in digital/mediatic discourses centred on educational uses of social media communities and interactions, most specifically some exemplary ones circulated within a Brazilian community page for 
English language teachers which is supported by the social media website Facebook, animated by thousands of participant teachers.

Assuming that not only do discourses name things but they also shape and create them by asserting new possible meanings (FOUCAULT, 1996), we believe that discourses are productive. Moreover, by analyzing them, we might get a better understanding of the identities of educational subjects being constituted throughout social media interactions.

Recalling Pêcheux (1983), a discourse is at the same time a form of rupture, both a way for recalling and forgetting - and a happening - given that "being inserted in a certain social and historic moment, a geographic space, [produced] to a determined social group, every discourse shows regularities and digressions which are updated within social and individual practices" (CORACINI, 2010, p. 23-24). ${ }^{1}$

Being immersed in a society fulfilled by digital forms of social communication and interaction has brought us to what Turkle (2006) calls a 'tethered' self: always 'on', always tied to one or another gadget/appliance which offers and (or) promotes ubiquity; a 'new state of the self' (2006, p.02 -05), constantly and psychologically in tune with (pre-selected) connections, the 'ones that really matter'.

The state of being (almost) always present (though bodily absent / away) has led us to reconfigure the notions of time and space. Social interactions mediated by media and supported by internet might happen within different grades of privacy - from being totally public to semi or fully private - as pointed by Turkle (2006, p. 03). This in/out; on/off condition, sometimes held simultaneously in multiple (and even different) social digital media spaces / times leads us to a myriad of interactions in which circulated discourses steadily manifest multiple identities and subjectivities on the move.

As all discourses are settled in specific moments in history and society, in order to proceed with our analysis, we are bound to explore the social aspects of contemporary world. Grounded on Usher and Edwards (1996), not only do we believe that a discourse analysis has to take into consideration the interlocutor's profile; the contextual production of the utterance and the social aspects of the analyzed discourses but we also perceive that such discourses are situated in a very specific historic and ideological context described by some as post-modernity. According to Usher and Edwards (1996), rather than a material state or a steady bunch of ideas, post-modernity might be understood as a state of mind, a different way to look at things and produce them; a self-referential posture/style.

\footnotetext{
${ }^{1}$ The authors of the current text are fully responsible for all quotation translations from originals written in Portuguese by the acknowledged authors.
} 
On a different note, Lypovetsky and Seroy (2008) discuss our current historic context under the concept of bypermodernity. In accordance to the later researchers' discussion, hypermodernity has instituted a singular state for culture as 'a culture-world', promoted by a capitalism centred in technology, which fosters a wholehearted consumerism and focuses on different new media forms and digital network based relationships (LYPOVETSKY \& SEROY, 2008, p. 07).

Bearing in mind the theories presented so far, we reckon that analyzing some exemplary posts circulated in the aforementioned webpage / community will then help us enlighten, throughout the materiality of discourse, the subjectivities, identities (and their representations) manifested / constituted by some Brazilian EFL teachers whilst enrolling in discussions in the community page, as they reveal their representations of their own learning/teaching processes and experiences.

\section{THE HYPERMODERNITY: TIME AND SPACE RECONFIGURATIONS}

It is common knowledge that space and time are two fundamental pillars of human life, as truly noted by Castells (2010). However, the researcher also points out the important changes the rising of a network society has brought to a social meaning of such dimensions.

No longer referred only as a geographic place, hyperspaces are revisited bearing in mind the social and historic support - besides the physical means for discourse socialization, i.e.; a locus for the materialization of social interactions, communication and, thus, subject constitutions and representations. From such a perspective, space 'is not a photocopy of society, it is society. Spatial forms and processes are formed by the dynamic of the overall social structure', (CASTELLS, 2010, p. 441). In other words, by changing social paradigms such as the way interactions are established, we do reshape space and time that, however turned into hyperspaces, cannot be dissociated from 'previous social-spatial structures', Castells affirms, explaining that 'this includes contradictory trends derived from conflicts and strategies between social actors playing out their opposing interests and values'(2010, p. 441).

Then, what happens to the time dimension when we take into account the (new) spatial forms that have emerged in the hypermodern, hyper-spaced connected society? We might think that it is shrunk into this new social space which, simultaneously, allows it to multiply - by adding ubiquity to the equation. Resorting to Castells' ideas (2010, p.441), 'space is the material support for time- 
sharing social practices', to which he adds that 'any material support bears always a symbolic meaning'.

We might then conclude that, in the hypermodern society we're currently living on, social media online interactions are both supported by and constituting of hyperspaces where discourses are shared, socialized, and providing an in and outing of subjectiveness, alterity and the various representations one displays of what / how they think others see others and also how others see themselves.

The omnipresent subject, almost always connected (at least to those they choose to be 'tethered' to) described by Turkle (2006) is socially and historically constituted by / in / throughout a hypermodern context. Paraphrasing Lipovetsky and Serroy (2008, p. 14), hypermodernity has been characterized by its (barely) immediate communication ways; a world where consuming objects such as digital gadgets has turned up to be indispensable, once they allow us to establish network communication by the means of two essential hypermodern tools : a) an assortment of medias and b) cyberspace.

A neo-liberalist mindset fosters the mercantilism of a set of symbolic representations of social imaginary and shared meanings - a culture which is global - thus promoting hyper-consumerism, in a capital-oriented society fashion.

The reconfigured transnational culture moves along accompanied by a conundrum: whilst being a totalitarian form of offering large-scale information (which not always means knowledge) and connectedness, hypermodernity is also highly individuality-motivational.

The concept of connectedness is brought here in lieu of the connections established by the means of new technologies - by the means of a variety of media and the internet - but it is also a symbolic reference to its meaning in the Mathematics field. We want to bear in mind that connectedness is one of the main properties in Topology: topological spaces are characterized by properties (a given $\mathrm{X}$ set) such as convergence, connectedness and continuity - elements that assure its main structure even upon transformation. The topological metaphor would then be that, by being constantly connected in the hypermodern world, the subject could somehow move around, ubiquitously, meanwhile maintaining a certain sense of place and structure, e.g. being part of a whole culture-world without giving up their own individuality.

Ideologically driven by needs of consumption (of both material and nonmaterial items), the hypermodern subject is overruled by an individualistic ideology, to which Lipovetsky and Serroy (2008, p. 14) call 'neo-individualism', which is characterized by individuals who can manage their time as they please; 
constantly worrying about consuming (possessing) the requested means in order to be as comfortable as possible in their own world - a world whose boundaries are somehow personalized (individualized) according to their own wishes, thus making it less subjected to socially collective limitations (LIPOVETSKY \& SERROY, 2008, p. 57). This social context brings us to a subject who is constantly poked by surges of need, to consume (material and/or ethereal) items which are largely networked, most often, online. The prêt-a-porter subjects rise up right then.

\section{THE PRÊT-À-PORTER SUBJECTS: (RE)VISITING BRAZILIAN EFL TEACHERS' DISCOURSES ${ }^{2}$}

When we qualify subjects with the expression prêt-à-porter we're obviously aiming at provoking reactions in/from our readers. The expression itself is believed to have been born within the fashion world, from where we have recovered it. We could as well have chosen the adjective 'customized', but we think that the customized subject is a means to bring to light the prêt-à-porter subject. As we relate this subject to the contemporary context, and to the constituting of identities, we have in mind the ephemeral nature as well as the consumerism that constitutes the subject in our current times.

According to Lipovetsky (2005), the 'prêt-à-porter' meant a 'democratic revolution' in the fashion world, since it represented an alternative model to the traditional way in which fashion was produced. It is a fact that, historically, the fashion model of the nobility was imitated by the ascending bourgeoisie and finally, in the beginning of the XX century, by the wealthy, in what was called Haute Couture. The prêt-à-porter model confronted this earlier and democratized fashion. Clearly, this democratization was an effect of the revolution in the clothing, accessories and shoe production industry, but somehow it aesthetically recovered the influence of Haute Couture, providing products to become accessible to a massive number of people. Thus, the aforementioned author stated that the prêt-à-porter 'era' coincided with the emergence of a society that, daily, turned their eyes and actions to the present; people who were euphoric about the New and the consumerism, besides being extremely hedonist and guided by individualistic ideals of pleasure (LIPOVETSKY, 2005, p.115).

\footnotetext{
${ }^{2}$ The concept of prêt-à-porter subjects was firstly brought up in a scientific article submitted to an international journal by Amarante and Andrade (2015), which remains unpublished. The current partial discussion around the concept may, then, be more extensively found in the referred article.
} 
Consequently, the concept of 'ready to wear' brings about certain effects of meaning that are intertwined with the ideals of the contemporary society, that is, with the need to be different; to innovate and to satisfy immediate desires. Such desires are then transformed into consumption desires of fashion items, which, from where we stand, go beyond clothing items: they include all technologic gadgets. Lipovetsky (2005) considers that this procedure brings as a priority a 'juvenile aesthetics', which would consequently oppose to the old symbol of tradition and of immobility.

If we understand that the current fashion is a trace - as a specific feature, an identity mark of contemporary society - we have to accept that consumption is harmonious with fashion. From our point of view, fashion offers the possibility of satisfying a concrete and immediate desire through the acquisition of a consumption object as well as an index of an individualization attempt by the subject who is presented with a plethora of options which are in constant change. These options, as stated by Lipovestky (2005), are no longer as rigid as they used to be and are in traditional fashion, since they allow the subject to identify (or not) themselves with several elements that constitute these changing options, transforming them into multiple, heterogeneous ones.

The way we see fashion is then articulated with the way we consider thinking subjectivities in contemporary times: the subject is multiple, fragmented, and, in a certain way, unique, since fixed labels are no longer accepted. In addition to this, we have to consider another characteristic of post-modernity / hypermodernity: the predominance of image, of simulacrum, of the 'spectacularisation' of the subject. This subject, according to Birman (2005, p.187), although trying to inscribe his/ her subjectivity to an "inside himself" (once his/her constitution is based on a self-centered, narcissistic economy), needs to expose his/ her privacy, as a form of exhibition and mise-en-scéne to present it to the social scene. Exposition of privacy may be a form to appease his/ her sensation of helplessness, loneliness and uncertainty, which would make of him / her an "out of self subject". This comes about due to the fact that the limits between the subject and the other (con)fuse themselves, since there is an attempt to seduce the other, to fascinate him/ her in face of the spectacle of images represented in social life (BIRMAN, 2005, p.190) and to covert $\mathrm{him} /$ her into ONE, eliminating, paradoxically, the difference, which is exactly what would nourish the singularities of each subject.

We must point out our agreement with Birman's (2005) point of view that in a narcissistic economy the subject lives in a mirror relationship, in which the other can be used to enhance his/ her own image and to satisfy his/ her individual 
needs, i.e., to his own enjoyment, thus making him/ her, not an "other" any longer, but an object of pure joy, that can be disposed at any moment, as if he/ she were a consumption object. We turn our attention again to the expression prêt-à-porter, which qualifies the noun subject. It seems to us that the prêt-à-porter subject is the one who would be ready to be used as an object of satisfaction to the other, offering himself/ herself as object, and, consequently, being under a desubjectifying process. $\mathrm{He} / \mathrm{she}$ is also ready to use the other as this object. In result, we consider that we are living a moment in which the current psychic economy values the way the other sees him/ her more than the relationship with the other, an effect of the strategic interposition of mediatic discourse within the consumption discourse.

It is important to point out that Baudrillard (2007, p.88), in his considerations on personal differences in relation to the consumption system, states that there is an industrial production of differences. These differences are never "personal, but differential, marginal and combinatorial". He considers as well that "they rather signal to their obedience to a certain code and to their integration into a sliding value scale" (BAUDRILLARD, 2007, p.89) than to a singularity itself. However, the author observes that there still is a current tendency to the anticonsumerism discourse, which he thinks is nothing but "meta-consumerism", since this characterizes the social groups that already have social status and that criticize the groups of 'Johnny-come-latelies, that would consume because of ostentation and whose consumption represents a sign of social distinction - and the consumed objects would not have value of use in themselves, but just symbolic value.

Thinking about the prêt-à-porter subject, we should also take into consideration that there is a tendency to aggregate a plus to the value of the products offered in the social market, what would make him/ her indispensable. This gives them a certain aura of solidarising and dedication in relation to the human being, since objects do not have an only purpose, but are impregnated with humanitarian values. We cannot forget that this is part of the capitalistic ideology that 'induces in the collective mentality the myth of a social order entirely devoted to 'service' and the well-being of the individuals', as stated by Baudrillard (2007, p. 170). The author illustrates his arguments in the area of advertisement, but we think that his considerations apply to any context in which it is possible, through the establishment of an intimacy tone with the reader/ spectator/ hearer, to simulate a given proximity, a confession voice between groups or between consumers and products.

Obviously, the author leads us to the understanding that there is a loss of the human relationship (spontaneous, reciprocal, symbolic)', when the reinsertion 
of signs (artifacts) is used to reinsert such relations into a consumption society. The other in annulled in these relationships, which are objectified. Riesman (apud BAUDRILLARD, 2007) referred to this kind of society as 'solitary crowd', constituted by a relationship in which one does not listen to the other, but only to himself/ herself and to his/ her own demands.

Castells (1999) describes the identities that are constructed in the late modernity', commenting that, with globalization, there is an interaction between local and global desires and the individuals who see themselves facing several possibilities, several life projects based rather on collective resistance than in historically built interests, relating to the networked societies. His hypothesis is that the constitution of subjects, in the centre of the process of social transformation, takes a route that differs from the one known during early modernity and the subjects, if and when constructed, are no longer grounded on civil societies that are in disintegration process, but rather as an extension of communal resistance (CASTELLS, 1999, p.28). The author, then, distinguishing between resistance and legitimating formation of identity processes, affirming that the identities in formation in postmodern times imply a subject in which the reason is no longer the unifying principle of the social world, because the illusion of identity unity becomes fragmented, giving room to multiple identities.

From our perspective this concept can be applied to the subjectivity constituted in and by the virtual world, a feature more and more inherent to the subject, since identity is understood as a continuous experimentation process, that are opposed to the fixed identities of modernity.

Lipovestky and Serroy $(2015$, p. 274-275) discuss the new forms of existence of the subject in social networks. They emphasize that currently the individual looks for an existence in a dorm of emotional and aesthetic consumption, expressing his/ her emotions, likes and personal inclinations through the net, in order to establish a bond, what allows a subjective construction based on sharing ('I am what I like').

Concerning consumption, Lipovesky e Serroy $(2015$, p.374) also state that we have come from a "hypnotizing" consumption (characterized by spectacularization) to an "hyperconsumption" - the one characterized at the same time by a production process and consumption of what it produces, a fact that explains what happens in social networks since the individual, in order to express his/ her likes, produces content to be liked, commented and shared. Receiving the other's approval, the individual has his/ her product consumed, disseminated and, at the same time, disseminates, discloses, divulges himself/ herself, i.e., is appreciated. 
Therefore, considering a prêt-à-porter subject implies reflecting about the construction of identity processes confronting modern and postmodern values in which the new forms of relationship with himself/ herself and with the other are established, passing on to a society marked by consumption relations, including interpersonal ones. If we take the concept of 'person', by Baudrillard (2007) and the representation of the singularity of the subject, we understand how the customized subject is a cause for the prêt-à-porter subject, since according Baudrillard

the "person" as a determination instance, disappears to give way to personalization. Then, the individual is no longer the focus for autonomous values, he / she only constitutes the term of multiple relations 'in a process of moving interrelations'. (BAUDRILLARD, 2007, p.181).

Baudrillard (2007, p. 181) resorts to Riesman (1996) who points out that the extra determined person feels, in a certain way, that he/ she is everywhere and nowhere, but anyhow, how capable they are of rapid intimacy, however superficial, with everybody.

It is clear that these moving interrelations, in the context of virtual social networks, especially the ones supported by Facebook (our research context), are constituted and constitute power relationships and, consequently, we must mention the notion of power as conceived by Foucault (1997) and, particularly, the notion of disciplinary power. On one side, the Facebook, as any other institution, is constituted by mechanisms which are meant to oblige the users to state their feelings and, thus, state themselves. This is a disciplinary power mechanism internally established in the constitution of Facebook, since its users have their bodies spatially organized and distributed in their own profile pages as well as in the ones of their friends and (timely) in the indication of the dates and times of their publications, status updating, likes, shares and comments (all of them features established by the Facebook web page, which actually leads its participants to manifest themselves as we've just explained).

In other words, visibility and utterability are panoptically controlled, as we take into account Foucault's description (1997) of the devices of the watchful eye - which are established in Bentham's architectonic project. On Facebook (taken as a larger device) it is possible to 'see' if the users are on or offline, and for how long they keep their status, as well as take note of what they liked, commented and shared, besides what they posted on their own timelines. Moreover, it is even possible to take a look at a timeline of any of those who compose one's group of friends thus scrutinizing users' profile outside one's group, not necessarily having to accept 'suggestions' (offered by the Facebook page) of new friends (connection) 
and/or publications that Facebook constantly and repeatedly brings to the eye of its users.

In this context, therefore, power works in a net system, in a rhizome-like way, as Deleuze and Guattari (1995) propose, since it allows the user to sense some degree of autonomy combined to a surveillance that turns everyone into stalkers.

\section{MEMES AND THE CONSTITUTION OF TEACHER'S IDENTITIES}

Lipovetsky e Seroy (2008, p. 46) comment on high-tech and its destructive effects of the individual in his/ her relations with the body, with sensible experience and with the others, pointing out that Internet has been seen as a danger to social bonds since it promotes an abstract and digitalized life, in which: the experiences are not collective lived; the insulated cocooning is a consequence of the enclosure of the new technologies and the body is no longer the real anchorage of life organizing, in its place, a 'disembodied, dessensualized and derealized universe'.

We understand that the process of dissembodiment, dessensualization, and derealizaton finds in the memes a discursive form that characterizes Facebook as a space for its presentification. Overall, we may define 'memes' as images, videos and/or sentences (often humor-witted ones) that got on a roll with the spread of WEB 2.0 and the sharing feature allowed by social media sites ${ }^{3}$.

In Post 1 (represented by Figure 1) we see a selected group of memes that have been added to an album created (and shared) by one of the teachers who takes part in the annalysed community. The line threading those memes is the underpinning idea that teachers do feel annoyed by some students' attitudes during their lessons, though it might be kind of like walking on thin ice to voice such feelings out loud. It is very interesting that the album is entitled 'Memes for the classroom' and not 'Memes about the classroom'. This choice of wording (using the preposition 'for' instead of 'about') has the effect of silencing reality, making us presuppose that such memes really are about the teacher himself / herself - the 'masochist being' that appears and reappears 88 times in the album - because he/ she is uncertain about their identity and strives for the attention of the others.

Moreover, he / she is represented by a fictional character, a process of disembodiment, dessensualization and derealization.

\footnotetext{
${ }^{3}$ You can learn more about it at: HEYLIGH. F. Evolution of Memes on the Network: from chain-letters to global brain. Available at: http://pespmc1.vub.ac.be/Papers/Memesis.html. Access: 07 Feb 07, 2015.
} 

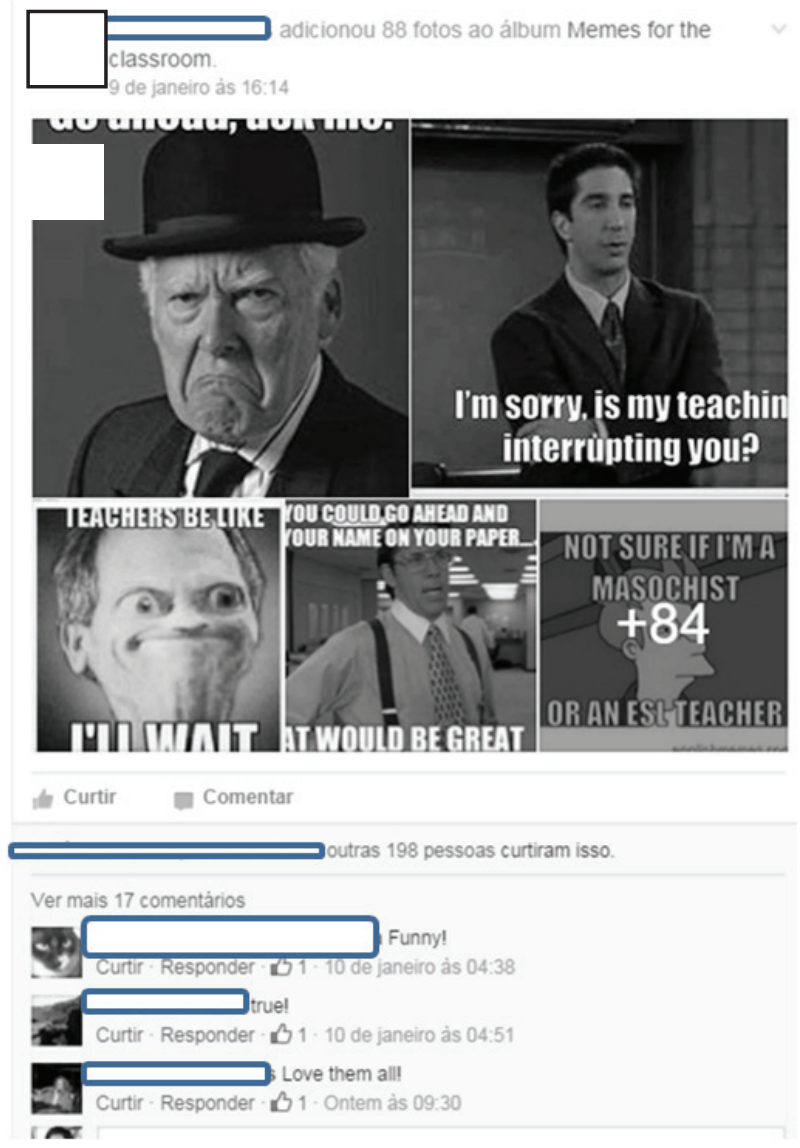

Picture 1. Post 1- memes meant to represent teacher's feelings towards students' attitudes in the class in a 'funny' way

Let us take, for example, the meme sporting a photo of Ross Geller (played by David Schwimmer), the fictional teacher character from the renowned and worldwide acclaimed TV series Friends. Ross is profiled as a typical 'nerd' teacher, who loves dinosaurs, works at a traditional University and has a penchant to museums. Amongst the other friends in the close group of main characters in the show, Ross is usually the one who makes silly and not-very-funny jokes (he is, after all, supposed to be a boring professor, his own choice of career being repeatedly mocked by family members and friends throughout the series seasons). Not only are his speech lines usually referred to as boring but also he tends to laugh at his own and other people's jokes and shenanigans in a strange, weird way, as if he was never really comfortable or confident enough in his own skin. His discomfort 
constitutes the teachers' identity, since he is ill-placed in a classroom where it seems there is no room for him, and where he has to beg for attention, since he shows to lack authority,

So, in terms of linguistic materiality, we may notice that a question is used to feign irony and mock students' misbehavior. Though the figure of speech of choice is irony, the wording selection shows witness; it is classy and respectful - the use of a polite form of interruption, "I'm sorry", besides expressing politeness and an appeal to grammar accuracy and formal register, is a confession of a fault. By doing so, the speaker (teacher/professor) keeps a respectful interchange with the absent interlocutor (the reprimanded learners), and tries to recover his locus of speech, in an attempt to reconstruct a power relation of sorts.

Moreover, the multimodal text (meme) provides a sample of ready-to-go discourse available for teachers to pick up and take (or wear?). Remarkably, it seems to be one of the most popular posts in the community, if one takes into account the total number of 'likes' it has got (198). The later aspect calls our attention once it is a given that the community page supported by Facebook offers lots of posts related to self-development teacher courses (many of them for free); pieces of news on recent educational policy decisions and many others that could have been regarded as more 'valuable' discourses, though they have proven to be much less appreciated in terms of the number of 'likes' they have got.

We should keep in mind that Lipovetsky \& Seroy $(2008$, p. 7) point out that in the hypermodern era in which media and cyberspace are the main tools to relate with the world, the main process in hyper individuation are grounded on the feelings of simultaneity and immediacy. Accordingly, the post above, through irony, contradictorily and simultaneously represents global standardization and identity fragmentation.

What we have stated about Post 1 , can also be said about Post 2 published in the same community and transcribed below in Picture 2: 

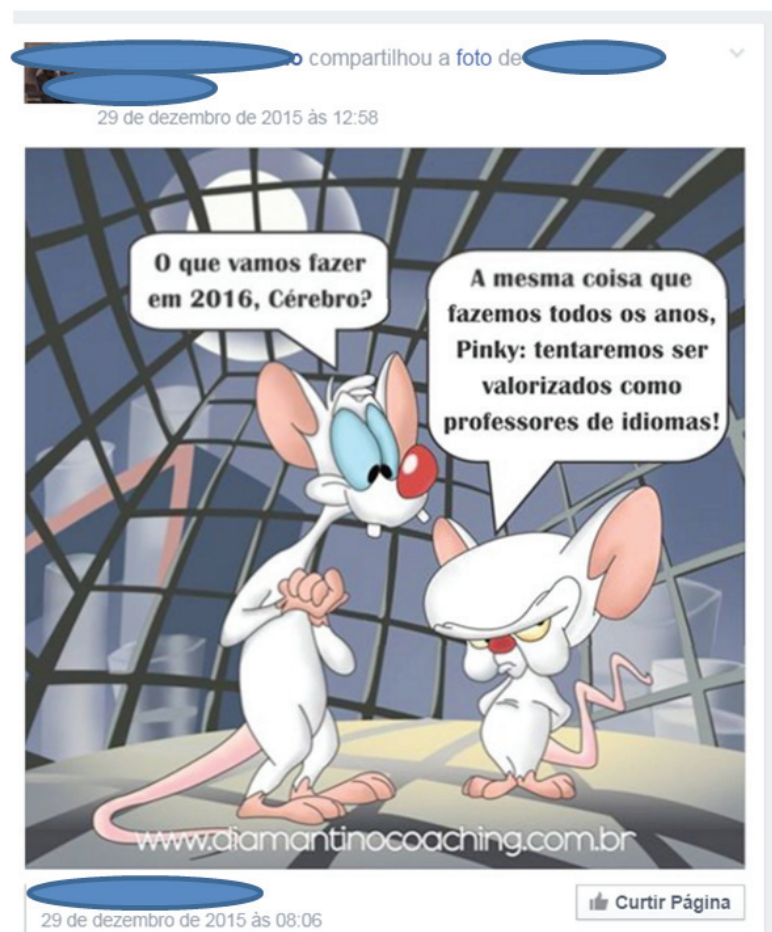

Picture 2. Post 2- meme from the album 'Memes for the classroom'4

In Post 2, the effect is also the one of helplessness, since year after year teachers must struggle for acknowledgement. Word selection of 'tentaremos' (we are trying) marks the teacher who is in a constant search for being valued although their effort is doomed to be unfruitful.

The obsolescence and uncertainty of the teacher are imagetically represented in the following post taken from the Facebook page.

\footnotetext{
${ }^{4}$ The dialogue in Picture 2 might be translated as: 'What are we doing in 2016, Cérebro?', 'The same thing we do every year, Pinky: we're trying to be valued as language teachers!'.
} 


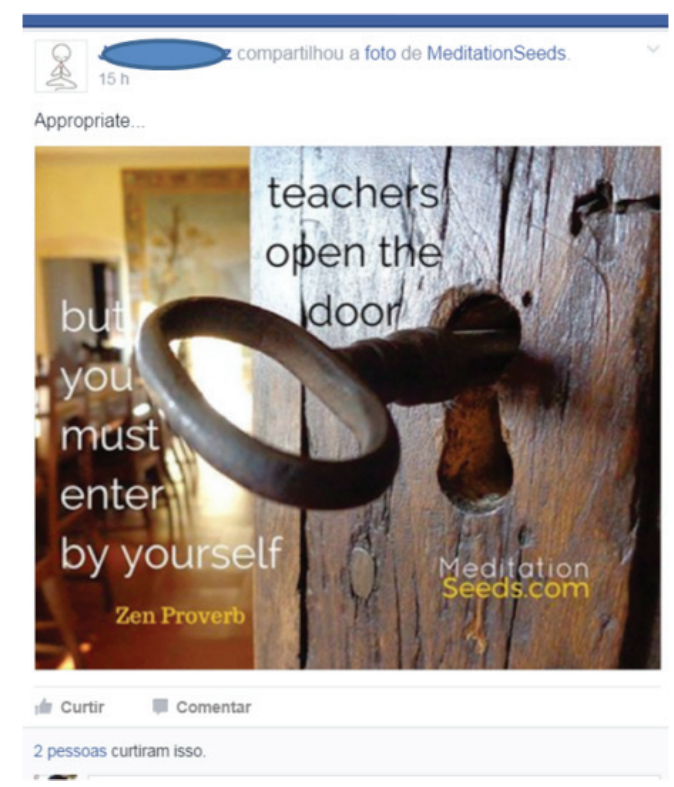

Picture 3. Post 3 - Post taken from the Facebook page

As we can observe in Picture 3, Post 3 shows a picture of a wooden rough door with an old-style key partially opening to a blurred background image of a room. Its characteristics bring to our memory the image of slaves' quarters and, thus, representation of the students as slaves and teachers as foremen who are in charge of the key. Consequently, power/knowledge relations (Foucault, 2004) are the constant remarks.

As Foucault (1996) points out, discourse produces truths, establishes truth regimes: who can say what, to whom, where and when. It puts into operation what Foucault (2001) called technologies of the self that provoke changes in the identity constitution of teachers who come to recognize themselves in this "same" who always is "Other".

On the one hand, it is interesting to observe that the saying that accompanies the picture is pointed out as a "zen proverb", what might be taken as, from our point of view, a "soothing" message for the teacher to keep calm. Its effect is taking the burden of the teaching/learning process out of the teachers' back, since everything depends on the students' initiative. Teachers' responsibility is at stake here: confronted by a reality that makes their work extremely heavy, it is necessary to provide them with "meditation seeds" so that they can stand the work overload given that they have lost the prestige they once used to have. 
On the other hand, it is interesting to notice that the enunciatee of the post is not 'teachers', although it was published on the Facebook page of a teachers' community. It is addressed to students. The topicalization of teachers in the first sentence and also the positioning of the sentence in the picture at the top and in the lighted area, in opposition to the adversative sentence, positioned in a shadowy area, remit us to unbalanced relations of the power that constitute traditional approaches to teaching. Thus, image and speech are contradictory and says much about the uncertainty of the teacher concerning his role in contemporary education and even his struggle to leave the Enlightenment ideals of teacher-student power relations and, consequently, the concept of a homogeneous subject.

We also have to notice that the use of the present tense in the first part of the statement conceals a general true, naturalizing the fact and taking it for granted: teachers do open the door, while the use of the modal verb in the second part urges the student to consume what the teacher has to offer. At the same time, the statement seems to point out to a promise of success, conveying that learning is a simple, easy process (such as the one of opening a door, provided that one's got the right key at hand).

The issue of ease/ difficulty to learn a foreign language as well as its social value is also a topic in the next post, sported in Picture 4.

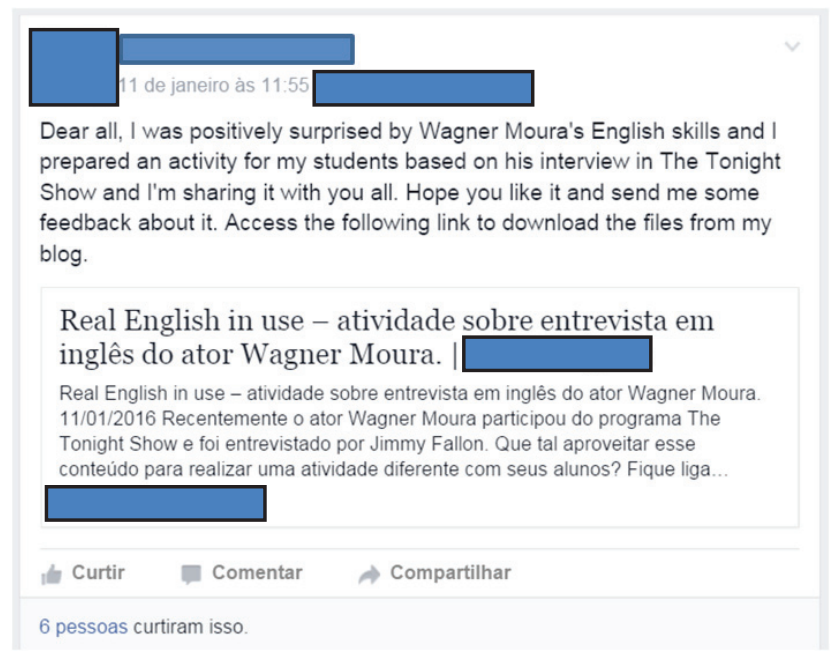

Picture 4. Post 4 - Post taken from the Facebook page ${ }^{5}$

\footnotetext{
${ }^{5}$ The text after 'Real English in Use' might be translated as: 'activity about an interview in English with actor Wagner Moura. Recently, the actor Wagner Moura has participated in The Tonight Show and was interviewed by Jimmy Fallon. What about taking advantage of this content to prepare a different activity with your students? Keep in tune...'.
} 
The post featured in Picture 4 was circulated in the teachers' community page by a teacher who wanted to share an activity she devised for her EFL lessons. The activity uses, as core material, an interview given in English by a Brazilian actor (Wagner Moura) who has recently got some international notoriety and press attention when receiving a Golden Globe nomination for his starring role in a film. What first calls our attention is the enthusiastic expression (of value) the teacher poses when stating that she was 'positively surprised' by the aforementioned actor's English skills.

Starting with a general polite and formal addressing locution ('Dear all'), the teacher states that not only was she impressed by the Brazilian actor's abilities concerning communicating in EFL but also that she didn't expect it to be (that) good (thus the use of the adverb 'positively'). The wording choice here drives us to a sense of low expectation towards Brazilians who are put on spot (such as sportspeople, for example, or actors and politicians, as well) meanwhile highlighting that not only was his English surprisingly good but also good enough to be taken as sample input to EFL lessons, thus pointing out to a somehow motivational act: one in which the teacher might even be expected to say something in the lines of 'See, though he is (also) a Brazilian, he can speak English well enough to be interviewed in a worldwide famous American TV show' - after all, there might be some hope for all the other (us) Brazilians trying to get the grips of the language as well!'

Wagner Moura is somehow respected and acknowledged due to his career these days, but it might be useful to remember that, situating the discourse in history, society and cultural terms, other aspects seem to arise from the mentioned post. Moura comes from a low-middle class, being born the son of a housewife and a low-ranked military worker from Bahia, a state in the northeast of Brazil. He was raised in a small town out of his state's urban centre. Having become a famous actor who might even speak English well enough to be considered a material for language class activities - in spite his social / financial / life origins and achievements - might be taken as an extra motivator for the teacher to feel like drawing her/his interview.

Also, the hyperlink provided in the post redirects the interlocutor to an activity posted in another media (a personal/professional blog), thus repositioning the Facebook participant to different space-times (should the interlocutor wish to navigate and keep tethered to it). The given link is entitled 'Real English in Use', thus redirecting us to even other different aspects which (re)constitute the enunciatee: 1. the belief / certainty / expression that there is such a thing as a 'real', opposed to a 'not-real', type of language (maybe a reference to the concocted language often presented by traditional language textbooks / didactic materials ?); 
2. 'real' English is supposedly one that is 'in use' - thus reporting a view/perception of language as a tool for a means; a capital; a gadget and/or product that might be acquired and then 'used' to foster social expression / participation / promotion / notoriety / recognition (and the list goes on and on). The wording choice in this case drives us to believe that, by publicizing (sharing) their activity, the teacher may as well as be requesting acknowledgement / approving from peers, by reinforcing the idea that this kind of authorial-original-authentic 'real English' material poses a somehow better approach to EFL teaching and learning than others (such as course books ?) might do.

Post 4 synthesises most of the theoretical aspects we brought about in our discussions in these article, such as the need for approval and likeness as stated by Lipovesky amd Serroy $(2015$, p.374), in a process fostered by a surging of either/ both consume and being consumed. It also points to a struggle of power of some sort as it puts the teacher in a leading position: the one expert who knows better (what to teach) as well as the a critic spectator (what 'English' skills some are might to be expected by teachers from certain individuals / learners).

Curiously enough, although Post 4 offers a class activity for free (which might be seen as a great help by some) it has got (up to the moment we took it from its posted page) much less appreciation than the 'funny' memes discussed before (only six 'likes'). Maybe consuming this kind of product is less interesting than producing and offering it for consumption and appreciation, after all...

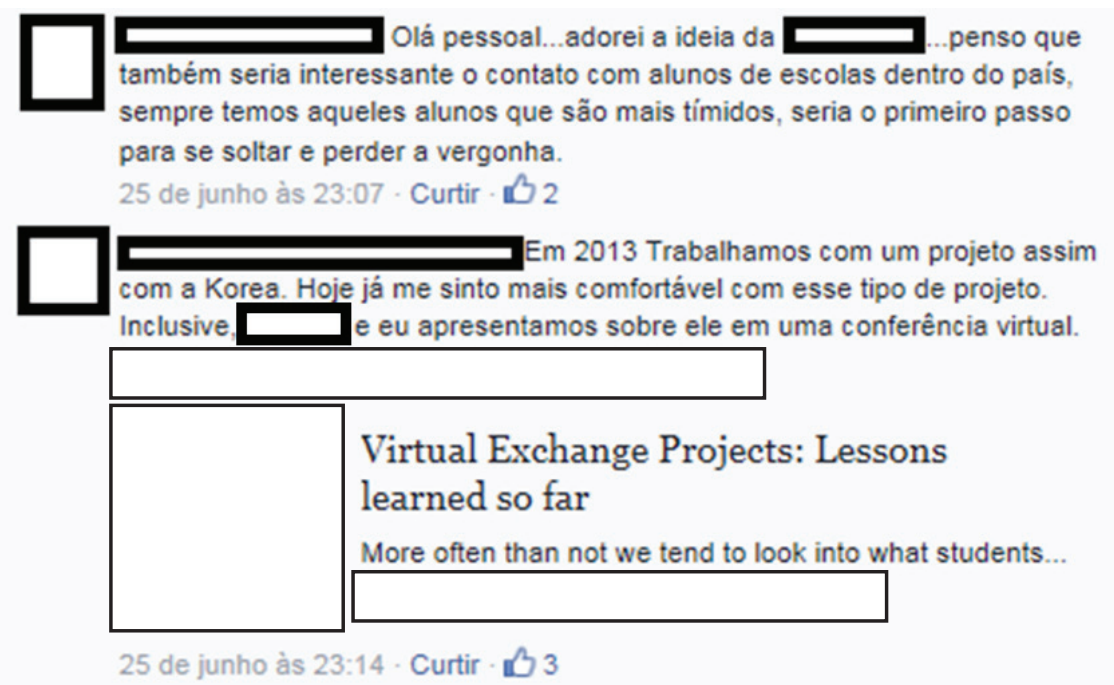

Picture 5. Post 5 - excerpt of a webinar from the teachers' community 
In Post 5 (reported in Picture 5) - an excerpt of a webinar from the teachers' community - we can observe that there is an effect of meaning of a certain resistance ('[...] penso que também seria interessante o contato de alunos de escolas dentro do país' /'I think that it would also be interesting the contact of students from schools inside the country'.) that is not taken into consideration. What is reappropriated, revalued and re-used is the initial saying ('Adorei a idéia da XXX' / 'I loved the proposal of XXX') that is rewritten in the statement of the next interagent, with great efficacy, firstly by making good use of the pendulum effect of transition between collective and individual and back to collective, materialized in the use of verbal forms, and secondly, by resourcing to the collective narrative as illustration to the argument ('Trabalhamos com um projeto assim com a Korea.') 'We have worked in a similar fashion in a project with Korea'), to the narrative of the self ('Hoje já me sinto mais confortável com esse tipo de projeto.'/ 'Nowadays, I feel more comfortable with this type of project.'), and, then again, to the collective narrative ('Inclusive, XXX e eu apresentamos sobre ele em uma conferência virtual.') "As a matter of fact, XXX and I have presented it during a virtual lecture.').

The post samples the inclusion of a hyperlink and a picture, which convey the marketing process of knowledge and the practice of re-inscribing oneself in the discourse, a characteristic of the consumption society and o spectacularization. This re-stating reoccurs so rapidly that, in the following minute, as we can see below in Post 7, the second inter-agent also makes use of the imagetic and digital illustration, bringing about the effect of reinforcement of a desire to be consumed, of having his knowledge consumed (autophagy) and, at the same time, obliges the first inter-agent to consume, or better saying, stating the consumption, what we can observe happening only 5 minutes after the first insertion. This time interval, obviously, was not enough to the first inter-agent to really consume the 2 previous insertions and then, consumption itself becomes simulacrum.

In other words, the freedom promised by neoliberal marketing does not find room, due to the fact that, within the limits of the territory of the learning community, what happens is the exercising of disciplinary power, with the distribution of bodies in pre-determined times and spaces.

As we have been demonstrating within our analysis, social networks constitute and are constituted by Power relations of the disciplinary kind and, in this context, Foucault's perspective that the neoliberal theory and, with it, the marketing process that constitutes contemporaneity could be a form of elaborating desubjectification practices (LAGASNERIE, 2013, p. 162) falls flat, as we pinpoint in our analysis of Post 6, showed by Picture 6. 


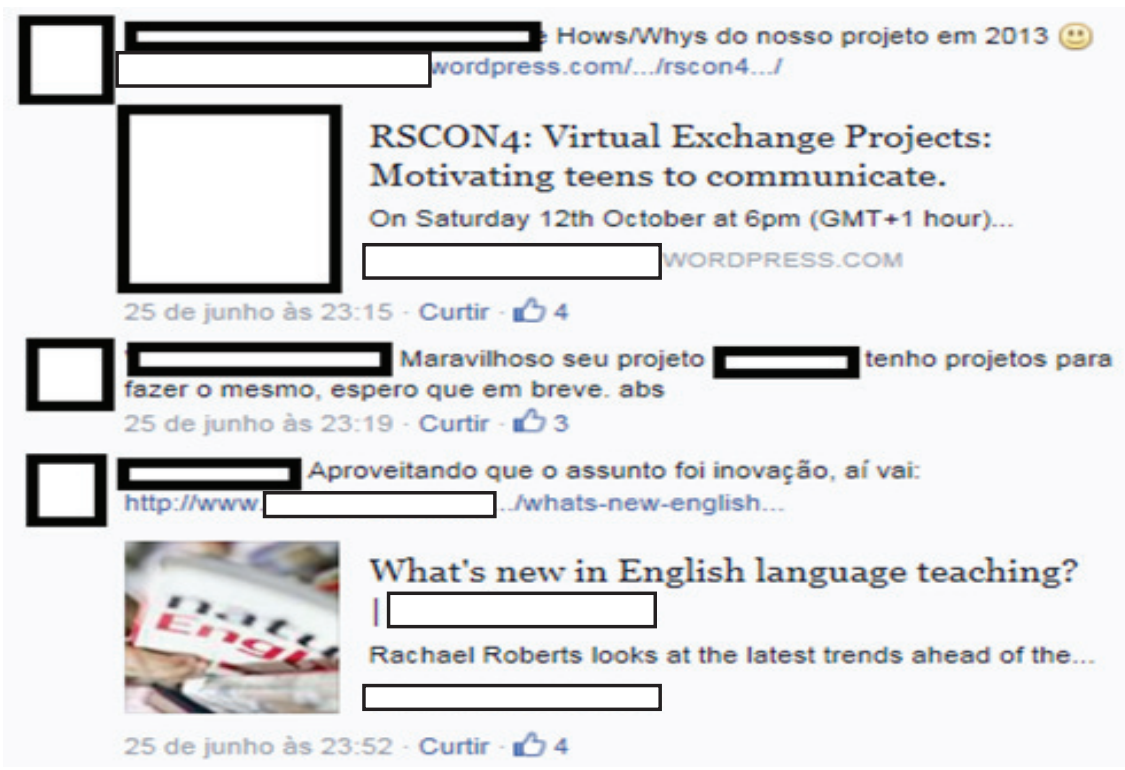

Picture 6. Post 6 - excerpt of a webinar from the teachers' community

In fact, subjection is materialized in the praise ('Maravilhoso seu projeto'/ 'Your Project is wonderful') to which the first inter-agent is obliged and to which resource to a strategy of self assurance follows ('tenho projetos para fazer o mesmo, espero que em breve'/ 'I have projects to do the same, soon, I hope') with meaning effects of resistance that are reinforced by the closing of the interlocution in the farewell statement ('Abçs.'/ 'Hugs.').

In spite of the above, we can consider that, in the battle for exercising powerknowledge, the opposition of a fulfilled project comes in contrast to a projectto-be, that should be complete in an indefinite period of time ('espero que em breve.'/ 'soon, I hope.'). It shows as well a closing which reveals a learner subject who abandons the arena, constituting the other as teacher. Then, solidarity and hyper-individualism alternate in the learning community, that is, verticalization and borizontalization coexist and the traditional roles of teacher and student are resumed, reshaping the learning community into a teaching community.

The interaction goes on and a third inter-agent comes out to stage, offering another product for consumption to the community members. His/her interference is highly legitimized, since they resort to the authority of the host institution of the article being recommended - an internationally acknowledged institution in the area of language teaching education. Mentioning it is then a part of the self production 
spectacle, an index of an autophagic process of knowledge. it is necessary to point out the emergence of a trans-aesthetic subject, as Lipovetsky and Serroy (2015, p. 372) named them. The self-marketing, from our point of view, is a feature of the prosumer (a producer that is also a consumer), the hyper-consumer who, increasingly, has to "work" to consume, becoming the co-producer of what he consumes while having to seduce the other so that what he produces is consumed.

In the following post, showed by Picture 7, the report of self-experience prevails, interweaving the individual and the collectivity, leading the subject to

Oi, pessoal. Pitaco rápido pós-discussão. Achei

interessante como a discussão acabou se enveredando mais para a parte tecnológica e menos para a parte metodológica (media vs. syllabuses and processes). Olha, se eu tivesse que levar uma delas para uma ilha deserta, acho que seria a segunda. Porque, vamos combinar, se é para fazer fill in the blanks usando o quadro interativo versão 2.0 ao cubo, what's the point. Estou exagerando, é claro, mas eu acho que tecnologia se sustenta mais quando ela vem como resposta a uma necessidade de inovação mais ampla. Tipo os language labs, que no final dos anos 50 , tiveram todo aquele boom por conta do audiolingualismo, que, por sua vez, tinha até objetivos militares e tal. Ou seja, a necessidade parece ter vindo antes (embora os labs já existissem desde 1900 e nada). Então, na minha cabeça, a hierarquia deve ser "temos um problema $\mathrm{x}$ / precisamos melhorar o learning dos alunos de forma y / dispomos de recursos $z$ / precisamos de recursos w" e não "olha que legal este recurso w, o que será que dá pra fazer?" Eu acho que é esta última hierarquia que acaba gerando gap-filling via iPad e coisas parecidas. Ou, atividades que são fun, but ultimately pointless. Sim, há exceções (i.e., idéias brilhantes que surgem a partir do medium e não do aim), eu sei...

Consigo pensar em outro exemplo que aconteceu comigo. Há alguns anos, enquanto ainda trabalhava em escola, embarquei na missão de melhorar o listening do aluno adulto $\mathrm{B} 1$ pra frente. $\mathrm{Li}$, estudei, pesquisei e cheguei à seguinte conclusão: falta bottom-up processing e foco em suprasegmentals, sound recognition e tal. Só que para fazer isso direito, sem tornar a vida do professor um inferno ("Avance até 0:47, clique em play, depois pause por 5 segundos em 1:18") eu precisei aprender a editar vídeo, o que me obrigou a dominar os softwares relevantes - na marra - e, posteriormente, a buscar formas de disponibilizar tudo isso online. Ou seja, o movimento começou na necessidade do público alvo, passou por metodologia e desembocou em tecnologia - como resposta a um problema. A hierarquia é meio por aí, eu acho...

consume and self-consume.

Picture 7: Post 7 - excerpt of a webinar from the teachers' community 
We have to notice that in Post 7, the user reports his own teaching experience, in a text that states itself as an opinion one, through, for instance, the use of 'pitaco'/ 'free unwanted advice', and the resource to verbal forms of the verb 'achar'/ 'think; guess'. As they expose the memory of their professional living, the participant tells an exemplary individual, in the form of a reflexive teacher, a missionary, a researcher. In the remembrance process, they consume themselves causing others to consuming them, organizing both their own subjectivity and the ones of the other members of the community. This is possible, from where we stand, because the post author is him/herself (when they use first person of singular verbal forms and pronouns) and out of themselves (when they say: 'Para fazer isso direito, sem tornar a vida do professor um inferno [...] eu precisei aprender a editar video'/ 'To do it the right way, without turning the teacher's life into hell [...] I needed to learn how to edit a video'), as pointed out by Birman (2005).

However, the lesson brought to light by the memory he offers for consumption is always modalized ('estou exagerando, é claro'/ I'm exaggerating, of course'; 'Sim, há exceções.'/ 'Yes, there are exceptions'; 'A hierarquia é meio por aí, eu acho.'/ 'The hierarchy goes like that, I suppose.'), revealing that, in the community, the disembodied existence requires the spectacularization of the experience of the self to provide the other with the imaginary participation in the reported experiences. By doing so, solidarity is exhibited; there is identification with the search to tend to the necessity of the target audience, with the challenges and hardships of the profession and, lastly, one dreams of an organized reality, aestethisized in the value of personal fulfillment through social change provided by a technologisized education - 'como resposta a um problema'/ 'as a response to a problem'.

From our perspective, the subject constituted in / by the text we are analyzing

[...] remits to the new hedonist relationship with the consumption that is oriented to the "feel", considering renewed emotions and "experiences" [...\} it os no longer a dedifferentiated, amplified, generalized consumption that looks for, in all the areas [...] new percepções, the fun, hedonist and emotional discoveries, sensations, vibrations. (LIPOVETSKY \& SERROY, 2015, p. 62-63)

That hedonist subject which presents itself to us in anthropophagic and autophagic processes (that materialize, for instance, in self-references and references in the imagetic and digital illustrations and in the last post, in the exacerbated resource to the self-narrative), acquires the meaning effect of attendance to a hyperthrophied demand, since sometimes it comes from the enunciator himself/ herself and sometimes from his/ her interlocutors. 


\section{LAST WORDS}

In this article, we analyzed posts published in a Brazilian English language teachers' community, supported by a Facebook Page, in order to examine the effects of the mediation of interactions by technology and the constitution of subjects.

If, for Derrida (1973), discourse as event only occurs if its nature is surprising and unexpected to the hearer or reader, when unpredicted effects escape, we have to point out to the possibility of novelty of this prêt-à-porter subject as part of a utopia of 'marketing' of the society as constructed in the neoliberal social theory. Lagasnerie (2013) believes that, in this neoliberal society, the market (because it is not based in an idea harmony, unity or coherence) is open to heterogeneity. Therefore, the market imposes "the image of a world essentially disorganized, of a world without a Center, unity, coherence and meaning." (LAGASNERIE, 2013, p. 93). Consequently, marketing would not be necessarily negative, since it could make room for multiplicity, plurality and immanence, notions that permeate Foucault's Power theory when he proposes that "the condition of possibility of power [...] is the shaky pedestal of the force relations that incessantly induce, because of their inequality, to states of power, although always local and unstable" (FOUCAULT, 1976, p.171-2). However, Foucault (2004) does not ignore that the emergence and the instauration of a neoliberal governamentality would produce the development of power, control and hierachy mechanisms.

From our point of view, we can then understand, from its spreading, that Facebook is one of the multiple normalization devices that invest on the bodies and model the subjectivities, as a part of these mechanisms. One can not deny that Facebook is the simulacrum of freedom, individual emancipation, because it acts, through the devices "publish", "like", "comment" and "share" in subjectification processes that constitute what we are calling the prêt-à-porter subject.

On the one hand, the fact that Internet seems (apparently) not to be under any type of regulation and, thus, the subject seems to be absent from it, masks Facebook as a limiting principle of individual rights. This is due to the fact that in the context of social networks we can observe an expansive knowledge domain that has as a consequence the death of the specialist, since everyone is posed as a specialist. Consequently, if hierarchy and control are less meaningful, content can be distributed and allocated in different ways, shaping, then, multiple co-locations and loss of content integrity, since the gratuity of content and tools plus open services and mashups give way to re-appropriation, re-valuing and re-use, with the prominence of business models, so that 'the collective power that seems to characterize the 
social networks is joined by collective intelligence, causing a collective social digital individualism, an apparent contradiction' (CONOLE \& ALEVIZOU, 2010, p.57).

Thinking about tour corpora, we consider that regimes of discourse/practice or Power/knowledge that we find into functioning in the teachers' community based on a Facebook page reveal disciplinary mechanisms that tend to the taste of the contemporary consumption society in which anthropophagic and autophagic processes rule and are materialized in the language (that, from a foucaultian perspective is social practice, is action over others), thus (re)shaping the ways by/ in which both in-service and pre-service teachers (and other language stakeholders) are being constituting in the hypermodern times.

In such a context, the subject commutes between what Lipovetsky e Serroy $(2015$, p. 376) state as a 'virtual donjuanism' which alternates with a 'new Narcissus on the mirror of the global screen', emerging in / from the processes of subjectification in the context of Facebook and gaining hyperbolic contours in the (il)limitations of virtual time/space that characterizes Internet and amplify, since we face an (un) restrained anesthetization of the subject and of his speech, in the spectacle of a life that is both individual and collective.

In summary, this aesthetization, contradictorily, gives and takes to / from events the possibility of novelty, since what we have is simulacrum and, so, the social bond to which Lacan (1993) refers seems not to tie.

Finally, we must say that this is not the only way to understand the contemporary subjects and their speech, since this would shape a unification and totalization featured in the Enlightenment Project in which the intellectual must produce discourses so that, as Foucault (1992) wanted, new regimes of truth come to be possible.

\section{REFERENCES}

AMARANTE, M. F. S \& ANDRADE, E. R. (2015). O Sujeito Prêt-à-Porter. Unpublished manuscript.

BIRMAN, J. (2005). Mal-estar na atualidade. Rio de Janeiro: Civilização Brasileira,. BAUDRILLARD, J. (2007) A sociedade de consumo. Portugal: Edições 70.

CONOLE, G. \& ALEVIZOU, P. (2010). A Literature Review of the Use of Web 2.0 Tools in Higher Education. Report commissioned by the Higher Education Academy. United Kingdom: The Open University, Available at: $<$ http//www.heacademy.ac.uk/assets/ EvidenceNet/Conole_Alevizou_2010.pdf>. Access: 20 jun 2013.

CASTELLS, M. (1999). O poder da identidade. São Paulo: Paz e Terra. 
CASTELLS, M. (2010). The rise of the network society (2 $2^{\text {nd }}$ ed.). Sussex: Wiley-Blackewell. CORACINI, M. J. R. F. (2010) Discurso e Escrit(ur)a: entre a necessidade e a impossibilidade de ensinar. In B.M. Eckert-Hoof; M.J.R.F.Coracini (Orgs.) (2010) Escrit(u)ra de Si e Alteridade no Espaço Papel-Tela. Campinas: Mercado de Letras, pp. 17-50.

DELEUZE, J.; GUATTARI, F. (1995) Mil platôs - capitalismo e esquizofrenia. Vol 1. Petrópolis, Rio de Janeiro: Editora 34

DERRIDA, J. (1973). Gramatologia. São Paulo: Perspectiva.

DERRIDA, J. (2001) Monolinguismo do Outro. Porto: Campo das Letras.

FERREIRA, F.T. (2008) Rizoma: um método para as redes. In Liinc em Revista, v.4, n.1, março 2008, Rio de Janeiro, p.28-40. Available at: http://www.brapci.inf.br/ repositorio/2010/06/pdf_40f5b401eb_001022.pdf. Access : 20 nov 2015.

FOUCAULT, M. (1976) La volonté de savoir. Paris: Gallimard.

FOUCAULT, M. (1980) Two Lectures. In: Power/Knowledge: Selected Interviews and Other Writings 1972-1977. New York: Pantheon Books. cap.5, p.79-108.

FOUCAULT, M. (1993) Microfísica do Poder. Rio de Janeiro: Edições Graal.

FOUCAULT, M. (1996) A ordem do discurso. São Paulo: Edições Loyola.

FOUCAULT, M. (1997). Vigiar e punir. Petrópolis, Rio de Janeiro: Editora Vozes.

FOUCAULT, M. (2001) História da Sexualidade I: A vontade de saber. Rio de Janeiro: Graal.

FOUCAULT, M.(2004) Naissance de la biopolitique. Cours au Collège de France (1978-1979). Paris: Gallimard-Seuil.

KEHL, M. R. (2004) O espetáculo como meio de subjetivação. In BUCCI, E.; KEHL, M. R. Videologias: ensaios sobre televisão. São Paulo: Boitempo.

LACAN, J. (1993) Seminário XX. Mais, ainda. Rio de Janeiro, Zahar Editor.

LAGASNERIE, G. de. (2013) A última lição de Michel Foucault. São Paulo; Três Estrelas.

LIPOVETSKY, G. (2005). O império do efêmero. São Paulo: Companhia das Letras.

LIPOVETSKY, G. \& CHARLES, S. (2008). A Cultura-Mundo-resposta a uma sociedade desorientada. São Paulo: Companhia das Letras.

LIPOVETSKY, G. \& SERROY, J. (2015) A estetização do mundo. Viver na era do capitalismo artista. São Paulo: Companhia das Letras.

PÊCHEUX, M.(1983) Papel da Memória. In: P. Achard et al. (2012). Papel da Memória. Campinas (SP): Pontes.

RIESMAN, D. (1996) A multidão solitária. São Paulo: Perspectiva.

TURKLE, S. (2006). Always-on/Always-on-you: The Tethered Self. Forthcoming in: Katz, J. (eds) Handbook of Mobile Communications and Social Change, Cambridge, Ma: MIT (press). USHER, R. \& EDWARDS, R. (1996) Postmodernism and Education. New York: Routledge.

Recebido: 31/01/2016

Aceito: 05/07/2016 